\title{
Transit Oriented Development \& Social Equity: from Mixed Use to Mixed Framework
}

\author{
Francesco Cappellano ${ }^{1, a}$, Alfonso Spisto ${ }^{1, b}$ \\ 2“Mediterranea” University of Reggio Calabria, via Salita Melissari 89124, (RC) Italy \\ afrancesco.cappellano@unirc, ba.spisto@unirc.it
}

Keywords: Mixed Framework, Social Equity, Mixed Income, Affordable Housing, Gentrification, Transit Oriented Development.

\begin{abstract}
The paper aims at exploring the Transit Oriented Development's (TOD) potentials, focusing mostly on social equity aspects. Since TOD has totally embodied Smart Growth's principles, it is widely adopted world-widely to densify and connect urban areas, turning them into urban polarities. Its coherency also with Sustainable Urban Development's principles makes TOD suitable to European Urban Regeneration's initiatives, however entailing similar negative social externalities. We will identify those sensitive factors which constrain the achievement of social objectives, studying two cases of TOD, one in Europe and one in the USA. We will assert the need to go beyond concepts as mixed use and mixed income, supporting a mixed framework approach.
\end{abstract}

\section{Introduction}

In 1970s, the American suburbs, which experienced sensible growth during previous decades, started to face a decline due to worsening traffic congestions which encouraged people enjoying a less stressful commute to work [1]. The lack of amenities forced "suburbs (..) to become more than bedroom communities [2]." A shortage in family size, coupled with an enhancing immigration pace favored the spread of "non-family house" demand. Smart Growth theory faced these environmental and social issues with the following principles pointed out by Pacione [3]

- Mix Land Use;

- Take advantage of compact building design;

- Create a range of housing opportunities and choices;

- Foster distinctive, attractive communities with a strong sense of place;

- Preserve open space, farmland, natural beauty and critical environmental areas;

- Strengthen and direct development towards existing communities;

- Provide a variety of transport choices;

- Make development decisions predictable, fair and cost-effective;

- Encourage community and stakeholder collaboration in development decisions;

Transit-oriented development (TOD) embodies all the above mentioned principles and for those reasons has gained popularity as a means of redressing urban issues, such as traffic congestion, affordable housing shortages, air pollution, and incessant sprawl. Several factors have strenghten the public interest in TOD [1].

Beyond calling for new transportation infrastructures, TOD aims at maximizing benefits of transit conceiving stations as new "urban hubs" which should drive towards investment attractions, businesses attainment and in general to a neighborhood revitalization. It is certainly consistent with urban design principles highlighted by Calthorpe [4]:

- organize growth on a regional level to be compact and transit-supportive

- place commercial, housing, jobs parks and civic uses within walking distance of transit stops

- create pedestrian-friendly street networks that directly connect local destinations

- provide a mix of housing types, densities, and costs 
- preserve sensitive habitat, riparian zones, and high-quality open space

- make public spaces the focus of building orientation and neighborhood activity

- encourage infill and redevelopment along transit corridors within existing neighborhood

Although TOD has no universally accepted definition, it is feasible to take into account the one provided by Still: "mixed-use community, that encourages people to live near transit services and to decrease dependence on their driving [5]. In general, TOD does have three commonly-agreed upon characteristics: a high-quality walking environment, a mix of land uses, and higher-density development within a designated area (typically one-quarter to one-half mile) surrounding a transit station or stop [6]. His function aims rarely to 'create' new growth, but more typically to redistribute growth that would have taken place without the investment" [7].

Since TOD seems compatible with the Urban Sustainable Development's principles, it can be a useful as a tool for the European Urban Regeneration strategies and its principles are hereby pointed out in Table 1:

Table 1: Urban Regeneration Policies [8]

\begin{tabular}{|l|l|}
\hline DIMENSION & CONCERNS \\
\hline Economic & Job Creation, income, employment, skills, employability, development \\
\hline Social/Cultural & Quality of life, health, education, crime, housing, quality of public services \\
\hline Environmental & Infrastructure, built and natural environment, transport and communications \\
\hline Governance & Nature of local decision-making, engagement of local community \\
\hline
\end{tabular}

For those reasons, in last decades, Transit Oriented Development is booming all over the world [9]. However, TOD's Benefits showed in Table 2, are only one side of the coin.

Table 2: TOD's Benefits [10]

\begin{tabular}{|c|c|c|}
\hline Class of Benefit & Public Sector & Private Sector \\
\hline Primary & $\begin{array}{l}\text { - Increase ridership and farebox revenues } \\
\text { - Provide Joint development opportunities } \\
\text { - Revitalize neighborhoods } \\
\text { - Economic development }\end{array}$ & $\begin{array}{l}\text { - Increase land values, } \\
\text { rents, and real estate } \\
\text { perfomance } \\
\text { - Increase affordable } \\
\text { housing opportunities }\end{array}$ \\
\hline Secondary & $\begin{array}{l}\text { - Less traffic congestion and VMT-related costs, like } \\
\text { pollution and fuel consumption; } \\
\text { - Increase property values and sales tax revenues } \\
\text { - Reduce sprawl/conserve open space; } \\
\text { - Reduce road expenditures and other infrastructure } \\
\text { outlays } \\
\text { - Reduce crime } \\
\text { - Increased social capital and public involvement }\end{array}$ & $\begin{array}{l}\text { - Increase retail sales } \\
\text { - Increase access to labor } \\
\text { pools } \\
\text { - Reduced parking costs } \\
\text { - Increased physical } \\
\text { activity }\end{array}$ \\
\hline
\end{tabular}

Transit improvements, as public infrastructures and services, affect property prices in several ways as they might enrich the location desirability of properties improving "user's quality of life, hence increasing the demand, and, in turn, the prices of property" [11].

An extensive literature [12] witnesses the way in which land property values rise when a transit system is implemented within the nearby area.

In fact, the Center for Transit-Oriented Development estimates that the overall demand for housing near transit will grow from 6 million to 15 million households by 2030 [13]. 
The rationale is that housing and transportation costs are on the increase in the U.S. TCRP estimates that one in three American households now spends more than 30 percent of the income on housing, and one in seven spends more than 50 percent.

\section{Tod and social sustainability: a "mixed framework"}

It is wider award that the rise of property values generates gentrification. "Gentrification is a neighborhood change process characterized by increasing property values and incomes [14]. Another possible effect of the transit implementation might be the displacement defined as "a pattern of change in which current residents are involuntarily forced to move out because they cannot afford to stay in the gentrified neighborhood" [15]. Several factors might address gentrification in different measures [16]. Kahn argues that "the introduction of Walk and Ride stations induces gentrification, while Park and Ride stations attract the poor to live nearby"[17].

Another unintended consequence regards the potential loss of core riders. In fact "Transit-rich neighborhoods are more racially diverse, less wealthy and contain a higher proportion of rental housing than other neighborhoods". Therefore displacement phenomena could directly affect those groups of population (mostly blacks or hispanics, in majority low-income people) who represent the core riders. As Pollack claims, "if these residents are displaced from their neighborhoods and replace by higher-income, less diverse residents, the transit system that rely on them may suffer as well” [18].

According to Wardrip, "when accessibility benefits lead to rising housing costs in lower-income neighborhoods, long-time residents can be displaced unless appropriate policies are implemented to prevent this from occurring" [19].

In order to preserve existing communities, usually TOD projects provide new affordable housing units. However, their number, and distribution coupled with public amenities' availability (such as schools, health care, markets etc.) influence and affect directly the resilience of the existing residents. Thus, it is required a broader policy aiming at mixed-income communities near Transit.

According to Reconnecting America's Center for Transit-Oriented Development (CTOD) there is a growing consensus that communities providing housing for a mix of incomes produce better economic, social and environmental outcomes for all residents.

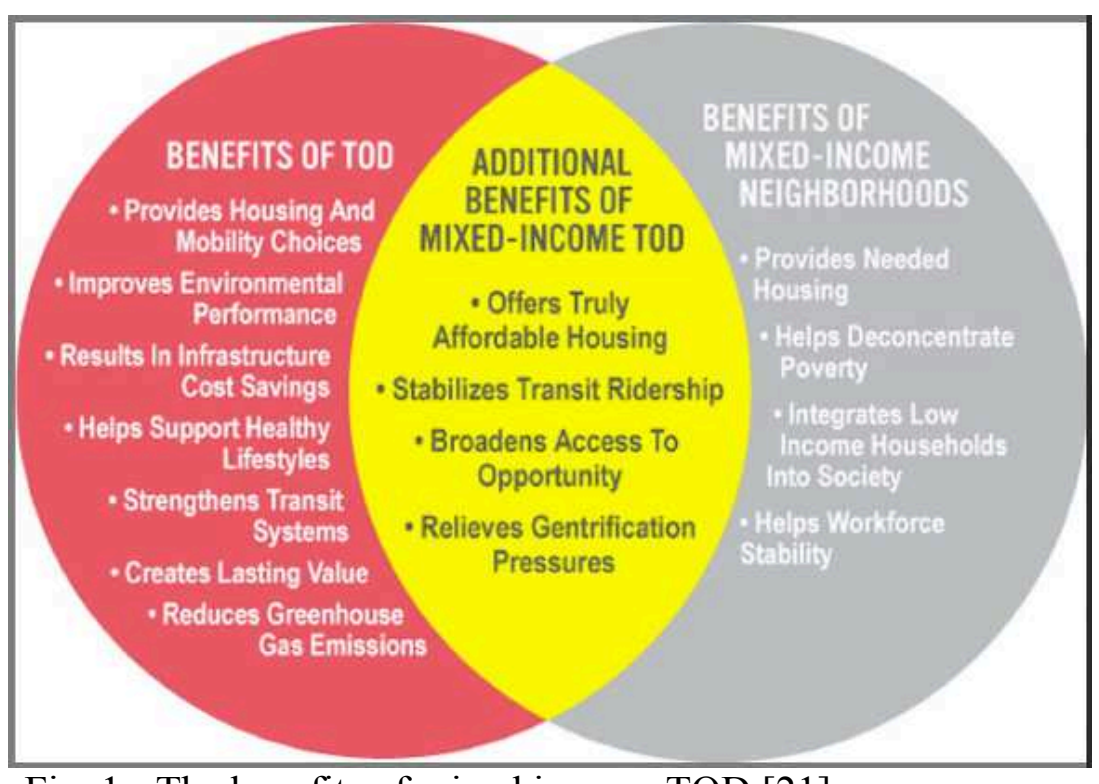

Fig. 1 - The benefits of mixed income TOD [21]
Mixed-income housing (...) makes it possible for people of all incomes to live in safe neighborhoods near well-funded schools and good city services, with greater access to a wider variety of jobs and opportunities [20].

The Fig. 1 to the side shows how mixed-income transitoriented communities combine the separate benefits of TOD and mixed income communities, while improving synergistic benefits that come from bringing the two together.

On one hand the integration of low-income people into neighborhoods with more 
affluent residents might produce what has been described as "Positive Gentrification"[22]. This means the middle class would play a role as a model of behaviors and attitudes, promoting and fostering mainstream social norms and expectations [23].

However, such kind of integration is still based on a market-driven development. Hence, higher income people will likely exert pressure to maintain safety and order in the neighborhood, enforcing rules to protect their investments [24] and threatening this physical coexistence.

Beside the mixed-income approach, the involvement of the communities during planning and implementation project processes seems to be fundamental to prevent the creation of new urban social struggles.

Therefore, we support the "mixed framework" (mixed use, mixed income, mixed partnership) that might be a way to paraphrase Lefebvre's concept of "the right to the city"[25] aiming at whole community development (physical + social + economic). Citing Joanna Duke : "Mixed income housing has the potential to overcome some of the barriers that are exacerbated by segregation, but it will take more than just physical integration. 'Right to the city' provides a foundation for social integration that goes beyond a superficial level of social interaction. Through encouraging diversity, a respect for different cultures can be fostered. Through appropriation, residents can feel meaningful connections to their communities, and through participation, residents can help shape outcomes for their communities"[26].

\section{The social impact: TOD in Italy and California}

We focused on two study cases (Rome, Italy and Fruitvale, Ca, USA) in order to show how TOD, in different urban contexts and with different private public partnerships may experience social equity troubles.

Extension of Metro Line, San Basilio, Rome, Italy;

Fruitvale Village Oakland, California, USA;

The methodological approach is based on an evaluation design of possible policy areas that can foster or hamper social advantages.

Beside the spatial configuration, these study cases have been chosen for three main reasons:

- Firstly, TOD in Rome is one of the first experiences in Italy of this kind of urban development strategy, so it's interesting to understand how a Smart Growth's tool performs in an Urban Regeneration plan;

- Secondly, the two study cases share a comparable development physical change and have an already existing community on which evaluating, in a qualitative way due to the lack of all needed data, social impacts of transformations;

- Thirdly, since the two study cases conduct different kind of PPPs with different trade-offs, they can show different unintended consequences related to that specific kind of PPP.

Rome, Italy:

In the study-case concerning Rome, the intervention comprises the extension of subway line B. The Track will be built totally underground for 3,8 km long. Along the line the building of two stations, San Basilio and Torraccia/Casal Monastero, is expected. The Latter represents the terminus of line B and takes its name from the two neighboring quarters. Just in the area outside the GRA (the freeway ring around Rome), an underground depot for trains is going to be built. On the ground, differently, a large car parking will be built, including a bus station. The biggest interregional and international bus lines which today get to Tiburtina Rome Station, will stop there. The principal aims of the intervention are:

- to let the extra regional lines stop in area of interest as, up to now, they pierce the GRA area to get to the Terminus in Tiburtina;

- to drain the vehicle traffic permitting the road railway frog, outside the GRA;

- to drain the daily traffic jam in via Nomentana and via Tiburtina; 
- to requalify the areas in San Basilio and Torraccia, offering a territorial inclusion, which is partial at moment;

- to serve the industrial area of "Centrale del Latte";

Fruitvale Village Oakland, California, USA:

Fruitvale Village transit-oriented development located next to the Fruitvale Bay Area Rapid Transit (BART) station in the Fruitvale district about 4.5 miles (7.2 kilometers) south of downtown Oakland, California. It is the central core of Fruitvale Village, a 19-acre (7.7hectare) area that includes a new housing development for seniors, extensive facade and street improvements, and both surface and structured parking spaces.

Developed by the Unity Council, a local nonprofit community development corporation, the Village comprises the following:

- 257,000 square feet (23876 sq mt) of building space built on former BART parking lots.

- An active, retail-lined connector between the BART station and the neighborhood's primary retail artery. This pedestrian street and plaza also serve as a major community-gathering place;

- 220 units of mixed-income housing and 68 units of HUD-assisted housing.

$-114,000$ square feet (10591 sq mt) of community services (clinic, library, senior center) and office space (including the Unity Council's headquarters);

- 45,000 square feet (4180 sq. mt.) of neighborhood retail (shops and restaurants);

- A 150-car parking garage within the buildings (plus a large parking structure for BART).

\section{Findings:}

Even though both cities used TOD as urban regeneration tool, the development process and the stakeholders' involvement were different, resulting in different outcomes.

We focused on social outcomes identifying one main policy area concerning the social equity. We pointed out two policies developed to either prevent or constraint social phenomena we describe. In particular, for each policy we addressed specific questions (Table 3):

Table 3: Evaluation Design

\begin{tabular}{|c|l|}
\hline Policy Area & \multicolumn{1}{|c|}{ Questions } \\
\hline $\begin{array}{c}\text { Land Value } \\
\text { Recapture } \\
\text { (Rome) }\end{array}$ & - Has been adopted any LVR plan during the project implementation process? \\
& $\begin{array}{c}\text { - Has LVR guaranteed any real redistribution of benefits (in terms of public } \\
\text { - Were they ensured within the entire area affected by the development? }\end{array}$ \\
\hline $\begin{array}{c}\text { Community } \\
\text { Involvement } \\
\text { (Fruitvale) }\end{array}$ & Has the power in fact redistributed through negotiation between citizens and \\
\end{tabular}

Rome:

Has been adopted any LVR plan during the project implementation process?

In Rome, the project economic coverage follows a project financing experiment with "value capture" obtainable through the estate valorization of six areas indicated by the City, subject to the city planning variation of current P.R.G (Italian urban-scale zoning tool). Limitations. On them, the Developer, identified by means of a call for bids, will be allowed to build development to sell to a third party for the economic return of the operation. In the areas close to new Subway Stations, the City specifies that the interventions, as resulting from the forecasting of Metro B s.r.l., will produce flats in 6-storied blocks $(40,000 \mathrm{sm})$, shops $(10,000 \mathrm{sm})$, green areas $(14,133 \mathrm{sm})$, public parking area $(6,637 \mathrm{sm})$, underground parking area $(20,000 \mathrm{sm})$. Among all areas, where the Developer will 
be allowed to build, it is expected that a total amount of 252,900 sm for Residential use and 105,100 sm for not Residential use will be built [27]. In the other hand hand, the private Developer will cover all economic costs related to the building of the Extension of the Metro line (around $556 €$ Billion) benefiting of around $200 €$ Billion of public funds.

Although the formula is named "Value capture", it is not intended to capture the "transit premium" effect on land values due the implementation of the projects. But It is oriented to exchange private investment into public infrastructure, such as metro line.

But I is oriented to exchange private investment into public infrastructure, such as metro line. Has LVR guaranteed any real redistribution of benefits (in terms of public services and spaces)?

The Developer is in charge of the building of the following public infrastructures: the extension of metro line, affordable units, a bike path and the restoration of the main square in San Basilio neighborhood.

Were public services either services ensured within the entire area affected by the development?

Considering the map of all placed where the Developer is allowed to build dwelling, the entire amount of affordable units will be placed in a marginal zone as showed in Fig. 2:

\begin{tabular}{|l|l|l|}
\hline Zone & Residential Use (sm) & Non Residential Use (sm) \\
\hline Monti Tiburtini & 13400 & 900 \\
\hline Monti Tiburtini & 15500 & 3700 \\
\hline Tiburtino & 25000 & 6000 \\
\hline Torraccia & 160000 & 80000 \\
\hline
\end{tabular}

Fig. 2: Masterplan the TOD in Rome Fruitvale Village 
Has the power in fact redistributed through negotiation between citizens and powerholders or has the community been involved only in the design process?

During the implementation process, one community design symposium has been held by Unity Council to conduct, during which architects offered designs for the development, inspired by ideas voiced by community members in attendance. Unity Council, as communty advocacy, organised several public meeting to share with residents ideas and goals of the project [28], (Transit-Oriented for All: The Case for Mixed-Income Transit-Oriented Communities in the Bay Area). However, the degree of partecipation of community can't be classified as "Partnership", according to Arnestein's "Ladder of Citizen Partecipation"[29], but only as "Consultation".

The Unity Council performanced more as community advocacy and social service agency, rather than an actual development partner, charged to guarantee the fair number of affordable houses. For this reason, the rising of housing costs, between 2000-2006, made the potential for displacement in the area very real and also made useless the partecipation process developed by the Unity Council

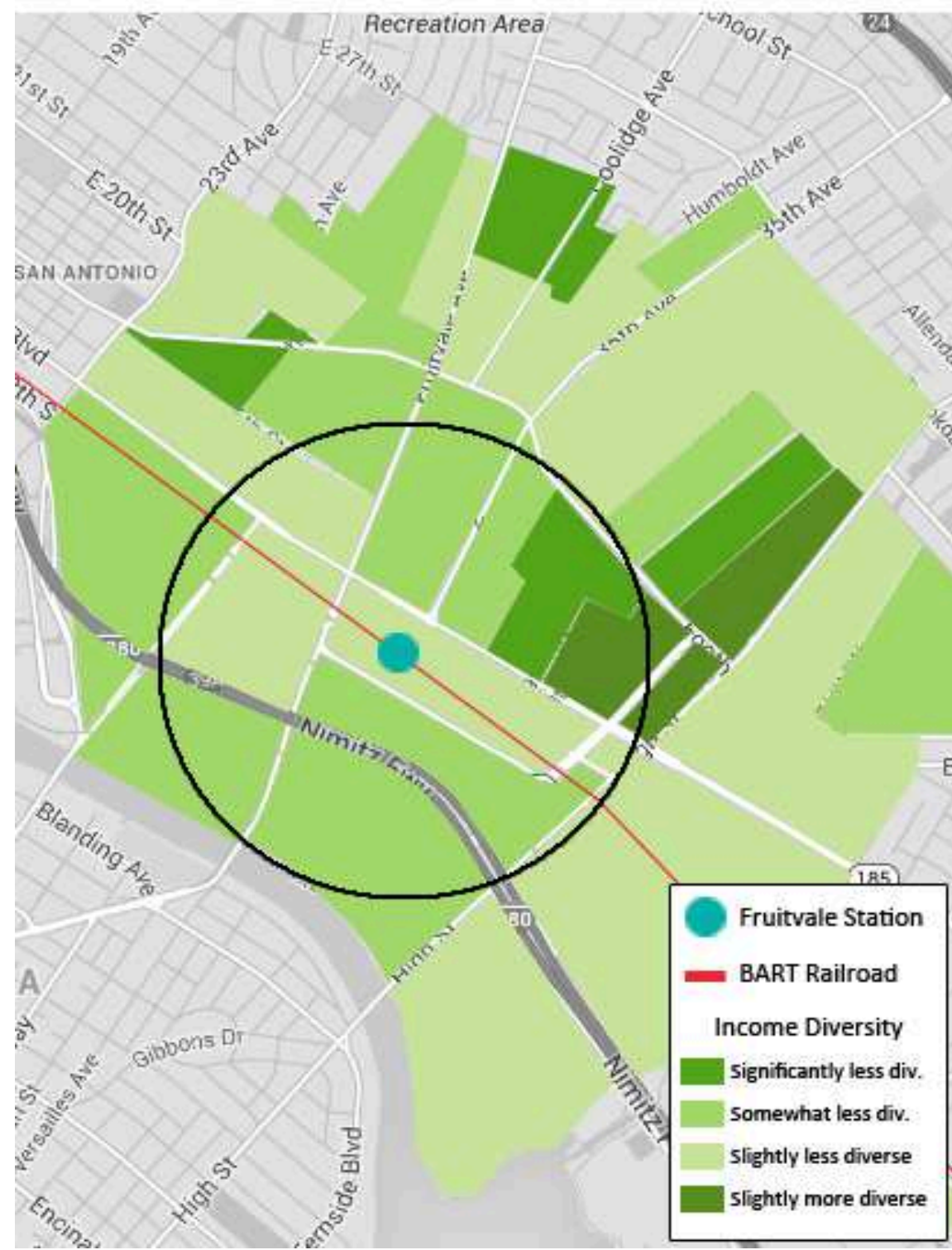
during the first phase [28]. Fig. 3 shows income diversity within half-mile radius from BART station. As we can see has not been achieved a real mix of different incomes so far.

Fig. 3 Income Diversity in Fruitvale [28]

"Significantly less diverse" is more than 1.65 standard deviations less than the Bay Area median; "somewhat less diverse" is between .825 and 1.65 standard deviations less than the Bay Area median; "slightly less diverse" is between 0 and .825 standard deviations less than the Bay Area median; and "slightly more diverse" is between 0 and .825 standard deviations more than the Bay Area median [28]. 


\section{Conclusions}

The evaluation design shows the importance of a well-balanced governance. Beside the public and the private, CDCs (community development corporations) as an actual decision making partner can be the missing element to enrich PPPs' performances and therefore reaching a "mixed framework" in which all the stakeholders are taken in count. In Rome, the project will enhance segregation and poverty concentration rather than those benefits that TOD is predicted to deliver. Whereas, in Fruitvale the premises concerning mixed income approach did not turn in reality as it is described in the picture above.

The mixed framework we support, not only guarantee deconcentration of poverty and at the same time protection of communities by threads as gentrification and displacement, but above all allows communities to be the first interlocutor of public and private sectors.

Communities, in this way, will play a role of main characters for the improvements of their neighborhood, according to their needs, their desires, their expectations: "The question of what kind of city we want cannot be divorced from that of what kind of social ties, relationship to nature, lifestyles, technologies and aesthetic values we desire [30].

\section{References}

[1] Transit Cooperative Research Program. Transit-Oriented Development and Joint Development in the United States: A Literature Review. Research Results Digest. Transportation Research Board, Washington, DC, 2002;

[2] H. Dittmar, G. Ohland, The New Transit Town: Best Practices in Transit - Oriented Development. Island Press (2004)

[3] M. Pacione, Urban Geography: a Global Perspective. London. Routledge. (2009)

[4] P. Calthorpe, The Next American Metropolis: Ecology, Community, and the American Dream. Princeton Architectural Press, New York (1993) pg 43

[5] T. Still, Transit-Oriented Development: Reshaping America's Metropolitan Landscape. On Common Ground, Winter (2002) pp. 44-47;

[6] National Research Council, TCRP Report 102: Transit-Oriented Development in the United States: Experiences, Challenges, and Prospects. Washington, DC: The National Academies Press, (2004)

[7] Transit Cooperative Research Program (TCRP), An Evaluation of the Relationships Between Transit and Urban Form, Research Results Digest, No. 7, Transportation Research Board, Washington, DC. (1995)

[8] A. Tallon, Urban Regeneration in UK. Routledege. (2012)

[9] H. Zeng, One the move: Urban Design for access. The city fix http://thecityfix.com/blog/onthe-move-urban-design-for-access-heshuang-zeng/, 2014

[10] R. Cervero , S. Murphy, C. Ferrell, N. Goguts, Y. Tsai, G. B. Arrington, et al. Transit-oriented development in the United States: Experiences, challenges, and prospects (TCRP 102). Washington, DC: Transportation Research Board. (2004)

[11] S. Mathur, Innovation in Public Transport Finance: Property Value Capture by 2014, Ashgate. (2014) In press

[12] K. Bartholomew and R. Ewing, Hedonic Price Effects of Pedestrian-and Transit-Oriented Development. Journal of Planning Literature (2011) 26(1): 18-34

[13] TOD 201, Mixed-Income Housing Near Transit Increasing Affordability With Location Efficiency. Reconnecting America (2009) 
[14] S. Pollack, B. Bluestone, C. Billingham, Maintaining Diversity in America's transit-rich neghborhoods: tools for equitable neighborhood change. Dukakis Center publications. (2010)

[15] L. Freeman , Displacement or succession? Residential mobility in gentrifying neighborhoods, Urban Affair Review. (2005)

[16, 17] Kahn, Gentrification Trends in New Transit-Oriented Communities: Evidence from 14 Cities That Expanded and Built Rail Transit Systems. (2007)

[18] S. Pollack , B. Bluestone, C. Billingham, Maintaining Diversity in America's transit-rich neighborhoods: tools for equitable neighborhood change. Dukakis Center publications. (2010)

[19] K. Wardrip, Public Transit's Impact on Housing Costs: A Review of the Literature. Insight from Housing Policy Research. Center for Housing Policy, 2011

[20, 21] Reconnecting America, Mixed Income Housing near Transit, www.reconnectingamerica.org/assets/Uploads/091030ra201mixedhousefinal.pdf (2009)

[22] S. Cameron, Gentrification, housing redifferentiation and urban regeneration: 'going for growth' in Newcastle upon Tyne. Urban Studies, (2003) 40.12, 2367-82

[23] W. J. Wilson, The truly disadvantaged: the inner city, the underclass, and public policy. University of Chicago Press, Chicago, (1987)

[24] J. Logan, H. Molotch: Urban fortunes: the political economy of place. University of California Press, Berkeley, CA (1987)

[25] H. Lefebvre: The right to the city (1968)

[26] J. Duke: Mixed income housing policy and public housing residents' 'right to the city'. Critical Social Policy, (2009), 29.1, pp. 100-20

[27] C. Bevilacqua, F. Cappellano, L. Zingali: TOD - Transit Oriented Development: a sustainable tool towards smart living, Proceedings of the 7th Conference of International Forum on Urbanism, (2013), pp. 275-284

[28] Reconnecting America: Transit-Oriented for All: The Case for Mixed-Income Transit-Oriented Communities in the Bay Area (2007)

[29] Arnstein, R. Sherry, A Ladder of Citizen Participation, JAIP, Vol. 35, No. 4, July (1969), pp. 216-224

[30] D. Harvey, The right to the city. New Left Review 53, (2008), September/October, pp. 23-40 